\title{
PENERAPAN MODEL DEMONSTRASI UNTUK MENINGKATKAN HASIL BELAJAR IPA SISWA KELAS VIII R5 MTS NEGERI 1 KOTAWARINGIN TIMUR
}

\author{
TRI LISDIYANINGSIH \\ MTsN 1 Kotawaringin Timur \\ Email : trisampit@gmail.com
}

\begin{abstract}
ABSTRAK
Penelitian ini bertujuan Untuk mengetahui peningkatan Hasil Belajar siswa setelah diterapkan Model Demonstrasi. Selama mengikuti pembelajaran, siswa kelas VIII R5 kurang bersemangat, hal ini disebabkan guru memberikan materi dengan metode ceramah, tidak memberikan contoh langsung. Siswa tidak respon dan kurang memperhatikan pelajaran. Mengakibatkan rendahnya nilai siswa, oleh karena itu Penulis melakukan analisis penyebabnya. Penulis membuat Penelitian Tindakan Kelas dengan menggunakan model pembelajaran yang lebih aktif. Penggunaan Model Demonstrasi diharapkan dapat meningkatkan hasil belajar siswa, khususnya dalam memahami materi Tekanan zat Cair. Model Demonstrasi bertujuan untuk memperjelas pengertian konsep dan memperhatikan cara melakukan sesuatu atau proses terjadinya sesuatu. Penelitian ini menggunakan penelitian tindakan (action research) sebanyak dua siklus yang terdiri dari tiga tahap yaitu: rancangan, kegiatan, refleksi. Subjek penelitian ini adalah siswa Kelas VIII R5. Data diperoleh dari hasil tes formatif, lembar observasi kegiatan, dan lembar wawancara. Dari hasil analisis didapatkan bahwa Hasil Belajar siswa mengalami peningkatan dari siklus I yaitu sebesar 45,33 dan ketuntasan belajar sebesar 33,33\%, menjadi 80,6 dan ketuntasan belajar sebesar 93,3\% pada siklus II. Penelitian ini dapat disimpulkan bahwa Penerapan Model Demonstrasi dapat meningkatkan hasil belajar siswa kelas VIII R5. Model Demonstrasi sebagai alternatif pembelajaran dapat diterapkan pada mata pelajaran lainnya sehingga hasil belajar dan kriteria ketuntasan maksimal dapat tercapai dengan baik.
\end{abstract}

Kata kunci : IPA, Hasil Belajar, Model Demonstrasi

\section{PENDAHULUAN}

Ilmu Pengetahuan Alam (IPA) adalah salah satu mata pelajaran yang merupakan cabang ilmu pengetahuan yang berawal dari fenomena alam. IPA didefinisikan dengan pengetahuan yang sistematis dan disusun dengan menghubungkan gejala-gejala alam yang bersifat kebendaan dan didasarkan pada hasil pengamatan. IPA juga didefinisikan sebagai sekumpulan pengetahuan tentang objek dan fenomena alam yang diperoleh dari hasil pemikiran dan penyelidikan ilmuwan yang dilakukan dengan keterampilan eksperimen dengan menggunakan metode ilmiah

Berhasilnya tujuan pembelajaran apabila tercapainya nilai ketuntasan maksimum pada satuan pendidikan. Guru yang berkualitas juga tidak menjamin siswa selalu mendapat nilai tuntas. Hal ini disebabkan karena siswa kurang memahami metode yang digunakan. Idealnya setiap siswa harus mendapat nilai sesuai kriteria ketuntasan minimal. Tetapi kenyataannya, siswa kelas VIII R5 yang berjumlah 30 orang tidak semuanya mencapai Hasil belajar yang memuaskan. Hal ini dapat dilihat dari hasil ulangan semester 1. Siswa yang mencapai ketuntasan hanya sebesar 36,4 \% dari 30 siswa. Dengan rata-rata nilai sebesar 59. Sedangkan nilai KKM adalah 60. Melalui sebuah diskusi dengan teman sejawat, penulis mencoba mengidentifikasi masalah penyebab rendahnya hasil belajar IPA siswa kelas VIII R5 adalah Kreativitas guru dalam mengembangkan model pembelajaran masih kurang optimal. Penulis mencari ide bagaimana cara yang tepat untuk meningkatkan hasil belajar siswa kelas VIII R5. Model Demonstrasi dipilih penulis dengan tujuan untuk memperjelas pengertian konsep dan memperhatikan cara melakukan sesuatu atau proses terjadinya sesuatu. Keunggulan Model Demonstrasi dapat memudahkan siswa dalam memahami konsep dan langsung dapat 
memperagakan apa yang dicontohkan oleh guru. Penerapan Model Demonstrasi ini diharapkan dapat meningkatkan hasil belajar siswa kelas VIII R5 khususnya dalam memahami materi Tekanan Zat Cair.

Berdasarkan latar belakang di atas, maka dapat dirumuskan suatu masalah sebagai berikut: Apakah melalui model Demonstrasi dapat meningkatkan hasil belajar siswa? Adapun tujuan penelitian PTK ini adalah untuk mengetahui peningkatan Hasil Belajar siswa setelah diterapkannya Model Demonstrasi. Sedangkan manfaat yang akan dicapai dalam penelitian ini adalah Bagi siswa : Penerapan Model Demonstrasi dapat meningkatkan pemahaman konsep Tekanan Pada Zat Cair. Bagi guru : Memberikan tambahan referensi dalam menggunakan model pembelajaran dan bagi lembaga : Sebagai informasi tentang alternative model pembelajaran yang efektif.

Roestiyah NK, (2001:83) dalam Istarani, (2011:101) menyebutkan bahwa Model Demonstrasi adalah model mengajar dengan cara memperagakan, kejadian, aturan dan urutan untuk melakukan suatu kegiatan, baik secara langsung maupun melalui penggunaan media pengajaran yang relevan dengan pokok bahasan yang sedang disajikan. Jadi "demonstrasi adalah cara mengajar, di mana seorang instruktur/atau tim guru menunjukkan, memperlihatkan sesuatu proses misalnya merebus air sampai mendidih 100 derajat cilcius, sehingga seluruh siswa dalam kelas dapat melihat, mengamati, mendengar mungkin meraba dan merasakan proses yang dipertunjukkan oleh guru tersebut berkaitan dengan Model Demonstrasi.

Penelitian Tindakan Kelas dengan menggunakan Model Demonstrasi ini juga pernah oleh di teliti oleh : Agreistin E. Peole, Vanny Maria Agustina, dan Lestari Alibasyah dengan Judul "Meningkatkan Hasil Belajar Melalui Metode Demonstrasi Pada Pembelajaran IPA di Kelas V SDN Taopa Kabupaten Parigi Moutong". Berdasarkan beberapa hasil penelitian tindakan kelas yang dilakukan peneliti terdahulu, maka Penerapan Model Demonstrasi dapat digunakan Penulis dalam mengembangkan model pembelajaran khususnya pada kelas VIII R5 dan diharapkan dapat meningkatkan hasil belajar siswa.

\section{METODE PENELITIAN}

Penelitian Tindakan Kelas (PTK) inii menggunakan Metode Penelitian Kualitatif dan Kuantitatif. (Bogdan \& Taylor 1975), Bogdan \& Biklen (2007) dalam Hamzah,(2019:35), menjelaskan bahwa penelitian kualitatif adalah salah satu prosedur penelitian yang menghasilkan data deskriftif berupa ucapan atau tulisa dan perilaku orang-orang yang diamati dalam satu konteks yang dikaji dari sudut pandang yang utuh, komprehensif dan holistik. Sugiyono, (2018:7) Metode Kuantitatif adalah metode yang menggunakan data penelitian berupa angka-angka dan analisis menggunakan statistik. Penulis memilih kedua metode ini disebabkan karena sesuai dengan kondisi siswa kelas VIII R5 berjumlah 30 orang. Prosedur pelaksanaan menggunakan Sistem Siklus. Setiap siklus meliputi planning (rencana), action (tindakan), observation (pengamatan), dan reflection (refleksi). Langkah pada siklus berikutnya adalah perncanaan yang sudah direvisi, tindakan, pengamatan, dan refleksi. Sebelum masuk pada siklus 1 dilakukan tindakan pendahuluan yang berupa identifikasi permasalahan.

Berikut ini adalah gambar rancangan penelitian tindakan kelas 


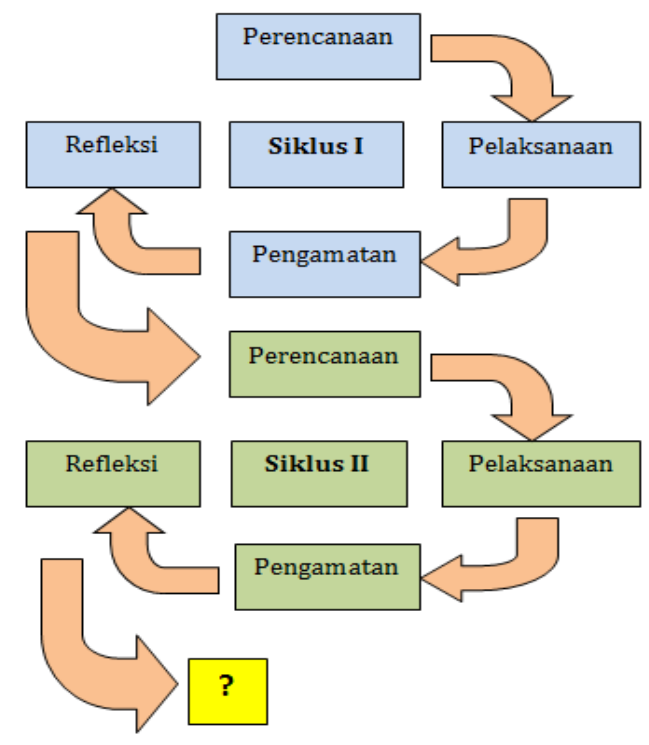

Gambar 1. Rancangan penelitian tindakan kelas

(Sumber: Stephen Kemmis dan Mc. Taggart (1998) dalam Ni Wayan Somawati, 2021)

Instrumen dan alat pengumpulan data dalam penelitian ini dengan menggunakan Observasi, wawancara. Menurut (Guba dan Linconln, 1981) dalam Hamzah (2019: 78) menjelaskan bahwa Observasi pada hakikatnya merupakan kegiatan dengan menggunakan pancaindera, bisa penglihatan, penciuman, daan pendengaran untuk memperoleh informasi yang diperlukan untuk menjawab masalah penelitian. Wardhani, (2007:2.1) menjelaskan bahwa Data dapat dikumpulkan dengan berbagai teknik, seperti observasi. Observasi merupakan salah satu teknik pengumpulan data yang sangat menentukan dalam PTK. Adapaun untuk memastikan bahwa penelitian ini valid, maka penulis menggunakan validasi internal. Menurut Hamzah, (2019: 102) bahwa validasi internal adalah upaya untuk memastikan akurasi dari informasi yang didapatkan. Penulis menggunakan sumber validasi yang berasal dari data tes ulangan akhir semester 1, portofolio, lembar kerja siswa. Dalam melakukan Peneltian Tindakan Kelas, data yang diperoleh cenderung berupa data kualitatif sehingga dalam Penelitian Tindakan Kelas ini penulis menggunakan analisis kualitatif diskriftif. Selain itu dalam penelitian ini, Penulis juga menggunakan metode kuantitatif. Sugiyono, (2017 : 243) menjelaskan bahwa bahwa dalam penelitian kuantitatif, analisis dihitung dengan menggunakan statistik sederhana yaitu: Penulis melakukan penjumlahan nilai yang diperoleh siswa, yang selanjutnya dibagi dengan jumlah siswa yang ada di kelas tersebut sehingga diperoleh rata-rata nilai tes. Untuk menentukan ketuntasan belajar, siswa mencapai skor sesuai dengan Kriteria Ketuntasan Minimum (KKM). Untuk mapel IPA nilai KKM sebesar 60. Indikator kinerja yang ingin dicapai pada Penelitian Tindakan Kelas ini adalah Meningkatnya hasil belajar siswa kelas VIII R5 dalam memahami materi Tekanan Zat Cair melalui Model Demonstrasi.

\section{HASIL DAN PEMBAHASAN}

\section{A. Hasil Penelitian}

\section{Pada Siklus I}

Pada tahap ini penulis mempersiapkan perangkat pembelajaran yang terdiri dari rencana pelajaran 1, LKS 1, soal tes dan alat-alat pengajaran yang mendukung. Pelaksanaan kegiatan belajar mengajar untuk siklus I dilaksanakan pada tanggal 20 Januari 2020 di Kelas VIII R5 dengan jumlah siswa 30 siswa. Dalam hal ini Penulis bertindak sebagai guru. Adapun proses belajar mengajar mengacu pada rencana pelajaran yang telah dipersiapkan. Observasi 
dilaksanakan bersamaan dengan pelaksaaan belajar mengajar. Pada akhir proses belajar mengajar siswa diberi tes dengan tujuan untuk mengetahui tingkat keberhasilan siswa dalam proses belajar mengajar yang telah dilakukan. Data hasil penelitian pada siklus I adalah sebagai berikut:

Tabel 1. Rekapitulasi Hasil Tes Pada Siklus I

\begin{tabular}{llc}
\hline No. & Uraian & Hasil Siklus I \\
\hline 1 & Nilai rata-rata tes & 45,33 \\
2. & Jumlah siswa yang tuntas belajar & 10 \\
3. & Persentase ketuntasan belajar & $33,33 \%$ \\
\hline
\end{tabular}

Dari tabel di atas menunjukkan Secara klasikal siswa belum tuntas belajar karena nilai kurang dari prosentase ketuntasan yaitu $60 \%$. Hal ini disebabkan karena banyak siswa yang belum memahami materi yang di bahas, siswa kurang bersemangat saat guru menjelaskan materi tanpa menggunakan Model Demonstrasi. Setelah melakukan pengamatan pada siklus I, guru melanjutkan ke siklus II, dengan harapan terjadi perubahan pada hasil belajar siswa ke arah yang lebih baik. Adapun Persiapan sama dengan siklus 1, yaitu RPP revisi, LKS, dan soal tes. Guru menggunakan model Demonstrasi dan membagi siswa menjadi berkelompok.

\section{Pada Siklus II}

Pada tahap ini peneliti mempersiapkan perangkat pembelajaran yang terdiri dari rencana pelajaran 2 , LKS, 2, soal tes dan alat-alat pengajaran yang mendukung. Pelaksanaan kegiatan belajar mengajar untuk siklus II dilaksanakan pada tanggal 27 Januari 2020 pada kelas VIII R5 dengan jumlah siswa 30 orang. Dalam hal ini penulis bertindak sebagai guru. Adapun proses belajar mengajar mengacu pada rencana pelajaran dengan memperhatikan revisi pada siklus I.. Pengamatan (observasi) dilaksanakan bersamaan dengan pelaksanaan belajar mengajar. Pada akhir proses belajar mengajar siswa diberi tes dengan tujuan untuk mengetahui tingkat keberhasilan siswa dalam proses belajar mengajar yang telah dilakukan. Instrumen yang digunakan adalah tes . Data hasil penelitian pada siklus II adalah sebagai berikut.

Tabel 2. Rekapitulasi Hasil Tes Pada Siklus II

\begin{tabular}{llc}
\hline No. & Uraian & Hasil Siklus II \\
\hline 1 & Nilai rata-rata tes & 80,6 \\
2. & Jumlah siswa yang tuntas belajar & 28 \\
3. & Persentase ketuntasan belajar & $93,33 \%$ \\
\hline
\end{tabular}

Dari tabel di atas menunjukkan bahwa hasil pada siklus II ini ketuntasan belajar secara klasikal telah mengalami peningkatan lebih baik dari siklus I. Pada siklus II Guru sudah melaksanakan langkah-langkah pembelajaran dengan penerapan Model Demonstrasi. Berikut ini grafik rekapitulasi hasil penilaian pada siklus I dan siklus II.

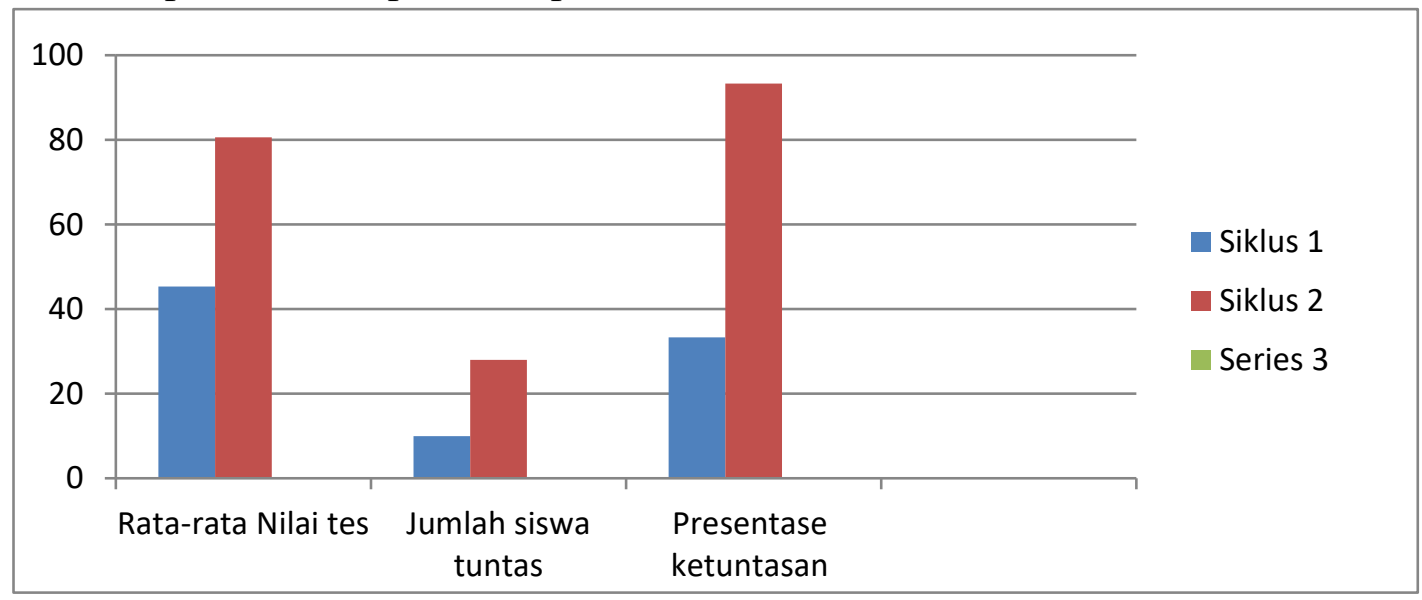

Gambar 4. Grafik Rekapitulasi Hasil Penilaian Persiklus 


\section{B. Pembahasan}

Berdasarkan data yang diperoleh melalui penelitian ini menunjukkan nilai rata-rata tes siswa mengalami peningkatan dari siklus I sebesar 45,33 dan ketuntasan belajar sebesar $33,33 \%$, menjadi 80,6 dan ketuntasan belajar 93,3 \% pada siklus II. Secara klasikal nilai rata-rata tes siswa menunjukkan peningkatan hasil belajar siswa dan ketuntasan belajar siswa sudah tercapai dengan baik. Peningkatan hasil belajar siswa kelas VIII R5 karena guru menggunakan Model Demonstrasi dalam menjelaskan materi Tekanan pada zat cair, sehingga siswa lebih mudah memahami materi dan mendapatkan contoh konkrit dan pengalaman langsung. Dengan demikian dapat dikatakan bahwa Penerapan Model Demonstrasi dapat meningkatkan hasil belajar siswa kelas VIII R5. Penelitian ini juga relevan dengan penelitian sebelumnya (Agreistin, Agustina, \& Alibasyah, 2016) menyimpulkan bahwa "Penerapan Metode Demonstrasi dapat meningkatkan hasil belajar siswa kelas V SDN Taopa". Siswa lebih paham terhadap materi yang diberikan guru karena siswa dapat melihat langsung contoh konkrit, sehingga kesalahan dalam pembelajaran dapat diminimalkan. Penelitian ini Sejalan dengan pendapat peneliti lain yaitu (Nahdi, Devi, dan Nurul, 2018) yang menjelaskan bahwa "Menggunakan metode demonstrasi dapat meningkatkan pemahaman siswa pada pembelajaran IPA materi sifat-sifat cahaya di kelas V SDN majalengka Kulon V Kecamatan majaengka Kabupaten Majalengka Tahun Ajaran 2017/2018”. Penggunaan Model Demonstasi juga berdampak positif pada siswa kelas VIII R5. Adapun dampak positifnya adalah siswa lebih dapat memperhatikan materi yang sedang diberikan guru, siswa dapat melihat contoh konkrit dan siswa mendapatkan pengalaman langsung. Melalui contoh konkrit kesan yang diterima siswa lebih mendalam dan tinggal lebih lama pada jiwanya. Hal ini sejalan dengan pendapat dari (Lisdiyaningsih,2020) yang mengatakan bahwa "Pembelajaran melalui Model Demonstrasi mempunyai dampak posistif terhadap meningkatnya hasil belajar siswa kelas VIII Ruang 5 MTsN 1 Kotawaringin Timur Tahun 2020.” Berdasarkan hasil observasi aktivitas guru dari Observer, penerapan Model Demonstrasi yang digunakan guru sudah terlaksana dengan baik. Siswa aktif dalam mengikuti pembelajaran. Kekurangan pada siklus sebelumnya sudah teratasi dengan baik.

\section{KESIMPULAN}

Penelitian Tindakan Kelas ini dilakukan berdasarkan rendahnya hasil belajar siswa kelas VIII R5 sehingga perlu diadakan penelitian untuk mencari sumber permasalahannya, melalui penerapan Model Demonstrasi dalam pembelajaran IPA diharapkan dapat meningkatkan hasil belajar siswa kelas VIII R5. Tindakan Penelitian sebanyak dua siklus. Berdasarkan hasil analisis yang telah dilakukan, diperoleh hasil belajar yang sangat baik, yaitu dari siklus I sebesar 45,33 dan ketuntasan belajar sebesar 33,33 \%, meningkat menjadi 80,6 dan ketuntasan belajar sebesar 93,3\%. Penelitian ini dapat disimpulkan bahwa Penerapan Model Demonstrasi dapat meningkatkan hasil belajar siswa kelas VIII R5. Perlu inovasi dalam pengembangan penelitian selanjutnya, bukan saja pada mapel IPA, tetapi pada mapel lainnya, sehingga peningkatan hasil belajar dan kriteria ketuntasan maksimal di berbagai mata pelajaran dapat tercapai dengan baik.

\section{DAFTAR PUSTAKA}

Departemen Pendidikan dan Kebudayaan. (1994). Petunjuk Pelaksanaan Proses Belajar Mengajar. Jakarta. Balai Pustaka.

Hamzah, Amir. (2019). Metode Penelitian Kualitatif, Literasi Nusantara, Batu

Istarani. (2011). Model pembelajaran Inovatif. PT Media Persada : Medan.

Kisworo, Marsudi W. Dan Iwan Sofana. (2017). Menulis Karya Ilmiah. PT. Informatika : Bandung.

Lisdiyaningsih, T. (2020). Peningkatan Hasil Belajar Materi Tekanan Zat Cair melalui Model Demonstrasi Pada Siswa Kelas VIII Ruang 5 MTsN 1 Kotawaringin Timur Tahun 2020. PTK: Tidak diterbitkan. 
Nahdi, D.S, Devi, AYdan Nurul, F. (2018). Upaya Meningkatkan Pemahaman Konsep Siswa Melalui Penerapan Metode Demonstrasi Pada Mata pelajaran IPA. Jurnal Cakrawala Pendas. Vol. 4, No. 2. 2018 core.ac.uk. https://scholar.google.com/

Peolo, A E, Agustina, V.Maria, \& Alibasyah, Lestari. (2016), Meningkatkan Hasil Belajar Melalui Metode Demonstrasi Pada Pembelajaran IPA di Kelas V SDN Taopa Kabupaten Parigi Moutong". Jurnal Kreatif Tadulako Online. Vol. 4 No. 6. https://www.neliti.com

Sugiyono. (2018). Metode Penelitian Kuantitatif, Kualitatif, dan R\&D. Alfabeta : Bandung.

Somawati, Ni Wayan, (2021). Penerapan Model Pembelajaran Group Investigation Untuk Meningkatkan Hasil belajar Peserta Didik Kelas IX 4 Semester 1 SMP Negeri 1 Banjarangkatan Tahun Pelajaran 2019/2020. Jurnal Pendidikan dan Pengajaran Vol. 1 No. 1. 2021.wayansomawati20@gmail.com

Wardani, I GAK. (2007). Penelitian Tindakan Kelas. Universitas Terbuka : Jakarta 